\title{
Assessing the Effects of Erzurum Nato Highway on Land Use and Environment
}

\author{
Meliha AKLIBAŞINDA ${ }^{1}$, Serkan ÖZER²
}

\begin{abstract}
The pressure on natural areas is increasing day by day in urban areas which cannot cover the needs of the increasing population. The area usage plans being insufficient or the disobeying to such plans; the areas with ecological importance and fertile agricultural characteristics are being opened for industrial or residential use. The misuses of the areas bring with them many ecological problems. With this study, environmental problems and the future effects brought of the Erzurum Nato Highway which goes through the middle part of Erzurum Plain and right next to Erzurum Swamp Area wetland have been dealt with. The area has the status of being a National Wetland and is located on the migration routes of the birds with its "Important Natural Area" and "Important Birds Area" characteristics. As a result of the wrong policies in the area, and by considering only the economic and technical facilities, ruining the area which has such an biological importance by making a new road in it will have consequences like losing the wetland and the plain, which may not be compensated for many years or may not be possible to compensate at all. In this study, the ecological importance of the area is emphasized and the amount of the land that was lost with the making of new roads and the areas being opened for construction was determined with the satellite views. And some future plans are suggested by considering the protection-using balance in order to prevent the misuse and protect the ecological characteristics.
\end{abstract}

Key Words: Environmental problems, Erzurum, misuse of the areas, planning, wetland

\section{Erzurum Nato Çevre Yolu'nun Alan Kullanımı ve Çevre Üzerine Etkilerinin Değerlendirilmesi}

\begin{abstract}
ÖZET: Günümüzde artan nüfusun ihtiyaçlarını karşılayamaz duruma gelen kentlerde doğal alanlara baskılar giderek artmaktadır. Arazi kullanım planlarının yetersiz olması veya bu planlara ekonomik, sosyal ve politik nedenlerle uyulmaması sonucu ekolojik öneme sahip alanlar ve verimli tarım toprakları sanayi ve yerleşim alanı olarak kullanıma açılarak elden çıkarılmaktadır. Yanlış alan kullanımları beraberinde toprağın yapısının bozulması, bitki ve hayvan türlerinin yok olması, su rejiminin değişmesi, tarım alanlarının yok olması gibi birçok çevre sorununu gündeme getirmektedir. Yapılan bu araştırma ile Erzurum ovasının ortasındaki Erzurum Bataklıkları Sulak Alanı'nın hemen yanından geçirilen Erzurum Nato Çevre Yolu'nun beraberinde getirdiği çevre sorunları ve gelecekte olası etkileri irdelenmiştir. Alanın Ulusal Sulak Alan statüsüne sahip olmasının yanı sıra kuş göç rotası üzerinde bulunuşu ile Önemli Doğa Alanı ve Önemli Kuş Alanı statülerine sahip olması önemini daha da artırmaktadır. Yanlış alan kullanım politikaları sonucu çeşitli ekonomik ve teknik kolaylıklar gözetilerek bu denli biyolojik öneme sahip alandan karayolunun geçirilmesinin sulak alanın ve ovanın elden çıkması gibi telafisi mümkün olmayan veya uzun yıllar alacak çevre sorunlarına neden olacaktır. Alanın ekolojik öneminin vurgulandığı bu çalışmada uydu görüntüleri üzerinden çevre yolunun yapımı ve çevresinin yapılaşmaya açılmasıyla kaybedilen alan miktarı ortaya konmuş, olası çevre sorunları değerlendirilmiş ve koruma-kullanma dengesi gözetilerek yanlış alan kullanımlarının önüne geçmeyi ve bölge ekolojik özelliklerini korumayı hedef alan planlama önerileri getirilmiştir.
\end{abstract}

Anahtar Kelimeler: Çevre sorunları, Erzurum, planlama, sulak alan, yanlış alan kullanımı

\footnotetext{
Nevşehir Hacı Bektaş Veli Üniversitesi, Mühendislik-Mimarlık Fakültesi Peyzaj Mimarlı̆̆ı Bölümü, Nevşehir, Türkiye

2 Atatürk Üniversitesi Mimarlık ve Tasarım Fakültesi, Peyzaj Mimarlığı Bölümü, Erzurum, Türkiye

Sorumlu yazar/Corresponding Author: Meliha AKLIBAȘINDA, melihaaklibasinda@nevsehir.edu.tr
} 


\section{INTRODUCTION}

The pressures on natural resources due to technological and economic developments in the world have increased and the urban areas have expanded towards the rural areas around them. In time, the usage styles of the areas have changed and the fertile agricultural lands, forests, wetlands and similar important areas with ecological importance have been opened for industrial and residential use. This development is considered as the display of the boom in the economy and has increased its pressure on ecology (Houghton, 1994; Ningal et al., 2008; Rimal, 2011).

The changes in the use of the areas have not only appeared in urbanization, but also in the competition among the use of the areas depending on the dynamics that may show differences in local and regional level. The construction areas continue their development mainly in fertile agricultural areas, and the agricultural areas show development by destroying the forests and the areas with natural flora (Doygun and Erdem, 2013).

One of the major problems in Turkey is the misuse of the agricultural areas. Mainly urbanization and industrialization, tourism, highways, railroads, energy and pipelines, dams, airports and sports facilities and similar investments, tile and brick workhouses and factories, open mines and similar activities are among the important factors that play roles in the misuse of the agricultural areas. The struggles of municipalities in expanding their urban areas are also influencing the decrease in the agricultural areas (Çelik, 2007).

These changes in the use of the areas brought with them various environmental problems. Water, soil and air quality, ecosystem processes, climate, bio-diversity and similar landscape components have always been influential in the process (Lambin et al., 2000; Cobelas et al., 2001).

The environmental pressures caused by the misuse of natural resources are among the important problems that are on the agenda of the developed countries and in Turkey as well. The most important reasons for the emergence of this problem is the protect-use balance and environmental values being not cared for at a sufficient level. Today, natural areas are facing serious pressures because of the demands for construction of public and private institutions. The most important of these construction demands is the highways, which play an important role in establishing a relation between the human beings and the nature and which shows the cultural use of the land (Tunay et al., 2008). The highway routes attract the industry and residence because highways provide ease in transportation and cause a lot of problems for the areas which they cover and for the human and environmental health on their routes (Çakar, 2007).

When the routes of highways are determined, economic and administrative benefits are cared for much; however, the long-term environmental effects of the highways and the human pressure on the same area are neglected. For example, the effects of the highways that pass through wetlands on biodiversity may not be observed in short term; and the increasing human activities in the same area cause the disintegration of habitats in the long run, disappearance of local species, invasion of exotic species and similar local and regional biological diversity (Findlay and Bourdages, 2000).

Wetlands provide proper nutrition, reproduction and shelter for many species, and affect the climate in a positive way, balance the ground water and purify the polluted water (Houlahan et al., 2006). The human activities in wetlands and the use of the areas nearby affect these functions greatly. In terms of biodiversity, the $85 \%$ of the wetlands, which have social and economic value, are under the threat of human beings. $75 \%$ of the wetlands are agricultural areas (e.g. watering and drainage); $35 \%$ are the areas for industrial development; urban expansion and wastes, 75\% illegal hunting; $40 \%$ excessive fishing; 30\% overgrazing of the farm animals and burning (Eken et al., 2006).

In this study, the ecological importance of Erzurum Plain, which is a wetland, has been determined, and the use of the area and the possible environmental effects of the Nato Highway, which was made in the area have been evaluated; and the possible precautions have been discussed and a proposal plan has been suggested. 


\section{MATERIAL AND METHOD}

The material of the study is the Erzurum Nato Highway which passes through the Northern side $6 \mathrm{~km}$ off the city center of Erzurum and its nearby areas. The city of Erzurum is located in the $40^{\circ}$ $15^{\prime}$ and $42^{\circ} 35^{\prime}$ 'eastern longitudes and $40^{\circ} 57^{\prime}$ and $39^{\circ} 10^{\prime}$ northern latitudes on the Northeastern part of Eastern Anatolian Region. The area in which the city center of Erzurum is located is called the Erzurum Plain. The plain which stretches through the Karasu River, which is a branch of the Euphrates River, until southeastern and northeastern part and cover an area of $870000 \mathrm{da}$. There is the Palandöken
Mountain Range on the southern part of the plain, which itself is shaped like a big hole and surrounded by mountains, and the northern part, there are the Dumlu and Gavur Montains; and Kargapazarı Mountains on the eastern part. The altitude changes between 1700 and $1900 \mathrm{~m}$.

The Erzurum Nato Highway, which passes through the Erzurum Plain was meant to facilitate the transportation between Erzincan-Kars for transit vehicles in 1995. The road starts from the northeastern of the Çiğdemli Village and ends in Nenehatun District (Fig. 1).

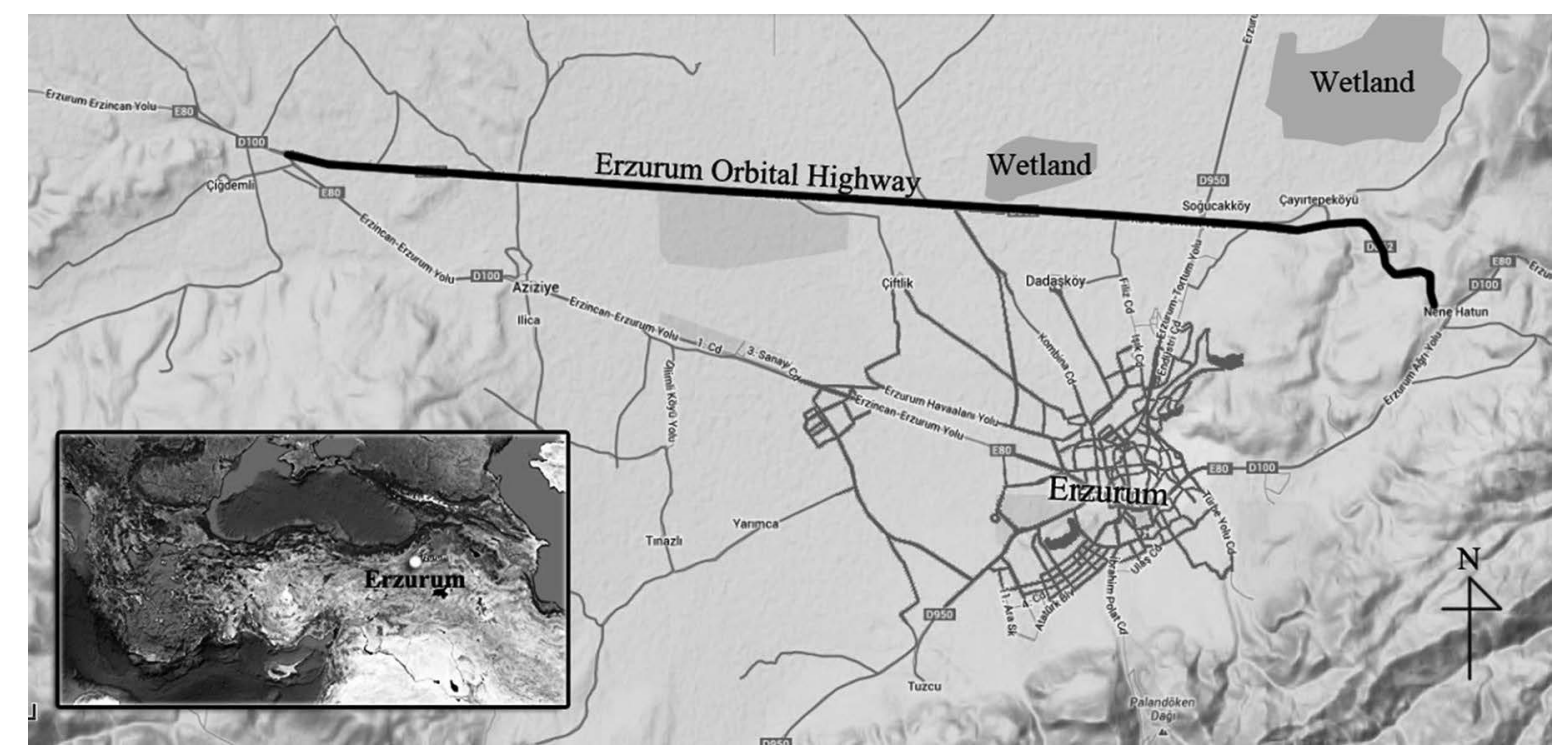

Figure 1. The Position of the Study Area

The literature was scanned in the scope of the study and the ecologic importance of the area was determined. The area was visited monthly especially in spring when the birds migrate and photographs were taken and observations were made to detect the changes that occurred in time. The existing facilities and the ongoing constructions on the route and their properties were determined. The amount of the area which is lost due to misuse of the land was determined by the area works and satellite images. The change in the use of the area in the recent decade was determined by using the 2005, 2009, 2014 satellite images of Google Earth. The studies on the misuse of the land were evaluated and the problems in the area and possible measures have been discussed. As a consequence, with the planting work in the area, which is especially important for the birds, a plan has been proposed in order to decrease the negative effects which have emerged due to the noise, visual and air pollution that have been caused by the road.

\section{RESULTS}

Erzurum Nato Highway passes through the fertile agricultural lands and through the wetlands which become wet due to the melting snow in the Erzurum Plain. There are the Important Birds Area (IBA) and Important Nature Area (INA) adjacent to the area, which has the statue of wetland with Erzurum Swamps (Fig. 2). 


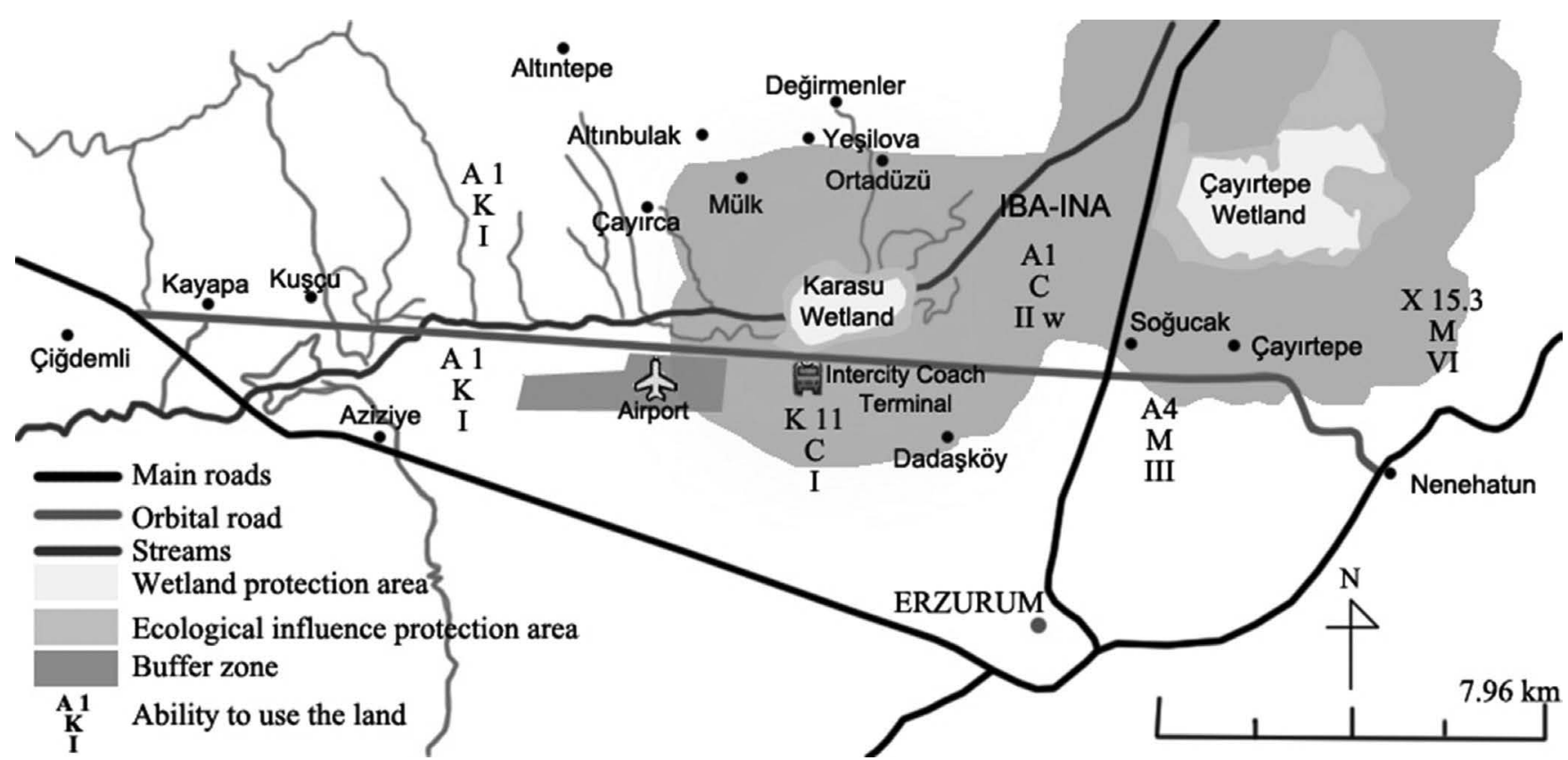

Figure 2. The current landscape properties of the study area

Erzurum Wetland is located on $3 \mathrm{~km}$ northern side of Erzurum city center. There is the Çayırtepe (Müdürge) Wetland on the eastern part of this area, and there is the Karasu River on the western part.

The area located over the Karasu River, which is one of the two main branches of the Euphrates River, consists of temporary and permanent swamps, seasonal wetlands and agricultural areas. There are temporary lake reservoirs in the middle part whose size changes according to the seasons, and surrounding wetlands. After the drying work in the area in the 1950s and 1960s, the lake and the reeds area became smaller and has had their shape today. The water in the plain is collected with two big drainage channels and sent to the Karasu River. Besides, there are smaller drainage channels surrounding the areas which are used as agricultural areas (Ekşioğlu et al., 2006). In the study area, which is located in the northern part of the Erzurum Airport, today, the seasonal wetland has left its place to grassland due to drainage. According to the land skill classification, most of the area in which the highway passes, is in the quality of I., II., and III. Class agricultural area. According to Anonymous (2000), the land in the Erzurum Plain is generally considered among the chestnut-colored soil groups and the soil in the plain has the organic mineral and alluvial characteristics in the ground area around the Karasu River (Özbek and Öztaş, 2004). Mainly, wheat, barley, rye, oat, potato, vetch, clover, trefoil are grown in the area.

Since the study area is located on the route of migration of birds, it becomes more important in the migration period. 52 different bird species have been determined by the Bird Research Association in the study area, and it has also been determined that 34 of them reproduce in the study area (Demir et al., 2011). According to the Red List Categories that are determined by the World Protection Organization (IUCN), it is one of the important points for the Vanellus gregarius, which is in the globally critical level (CR) of becoming extinct, to stop by on the route of migration. Meanwhile, the study area covers the criteria of being Important Natural Area because of the Tadorna ferrugginea and the reproducing Grus grus. In recent years, the number of the Chlidonias leucopterus, whose number reached tens of thousands once, has fallen to thousands only due to the misuse of the area. In addition, the Glaucopsyche arion butterfly, whose species is in danger at the regional level, also lives in the area (Ekşioğlu et al., 2006). 
The study area has a rich flora diversity and the endemic species Lepidium caespitosum Desv. and Dactylorhiza osmanica (K1.) Soo. and the Typha shuttleworthii W. KOCH ET SONDER, which are among endangered species within Europe, are among them. The important plants in the area are (Irmak, 2008); Populus alba L., Rosa dumalis Bechst., Rosa pimpinellifolia L., Allium atroviolaceum Boiss., Allium vineale L., Orchis sp., Gladiolus atroviolaceus Boiss., Iris spuria L., Crocus kotschyanus K. Koch, Dactylorhiza osmanica (K1.) Soo., Achillea biebersteinii Afan., Adonis aestivalis L., Alkanna orientalis (L.) Boiss. , Alyssum desertorum Stapf. var. desertorum, Anthemis cretica L., Butomus umbellatus L., Cerastium chlorifolium Fisch. \& Mey., Centaurea glastifolia L., Crambe orientalis L., Draba nemorosa L., Epilobium hirsutum L., Erysimum alpestre Kotschy ex Boiss., Galium verum L., Hyoscyamus niger L., Hyoscyamus reticulatus L., Inula aschersoniana Janka, Lathyrus aphaca L., Lepidium caespitosum L., Lotus corniculatus L., Lythrum salicaria L., Melilotus officinalis (L.) Desr., Onosma sericeum Willd., Plumbago europaea L., Potentilla palustris (L.) Scop., Ranunculus orientalis L., Salvia multicaulis Vahl., Taraxacum bessarabicum (Hornem.) Hand. Mazz., Typha latifolia L., Tragopogon dubius Scop., Vicia cracca $\mathrm{L}$.

In the past, the Erzurum swamp areas were one single area; however, today, this area is divided into four with the Erzincan-Kars and Erzurum-Artvin highways. Although there were no residential or industrial areas in the past, except for villages, with the Erzurum Nato Highway passing through the plain, and the Erzurum Airport being located in the area, the attraction of the area has increased. The city has developed towards this direction and has faced a fast construction in recent years. In 2013, the Erzurum Intercity Coach Terminal was moved to this area and the density increased too much.

In the measurements that were performed over the land works and satellite views it has been determined that approximately 852 da of land was lost in the area which has important characteristics in terms of ecology with the construction of the highway (except the crossover roads and access roads); 5375 da was lost with the opening of the surroundings of the road for construction (in total 6227 da agricultural land is lost).

There are Erzurum Airport, 4 crossover roads, 3 petrol stations, and an industrial zone, a lot of commercial companies and their storage areas, BOTAŞ Facility, and many other facilities whose constructions are still in progress on the route. When the satellite views of the years 2005, 2009 and 2014 are examined, it is observed that there were 10 company buildings on the highway route in the year 2005; and the number increased to 16 in the year 2009; and to 27 in the year 2014 (Fig. 3 ). The construction work increased by $170 \%$ in the last decade. In the year 2005, the construction work increased by $60 \%$; and in the period from 2009 to 2014 , by $68.75 \%$. It is obvious that there are increasing construction works in the area in recent years. In addition, the existence of areas that are evened around the highway implies that the construction work will increase in the near future. 



Figure 3. The construction work in the years 2005, 2009, and 2014 in the study area (Google Earth data have been made use of)

\section{DISCUSSION AND CONCLUSION}

As it is emphasized in the study, due to the misuse of the area in which various technical and economic benefits were cared for the Erzurum Nato Highway was constructed around agricultural lands and SNA and SPA areas, the wetland in the swamp area which has ecologically important functions. As Findlay and Bourdages (2000) stated in their studies, highways that pass through wetlands may affect the bio-diversity around them in the long run. Loss of plant species in such areas may show its symptoms after many years, and the loss in reptiles and birds may appear in around 8 years. The coverage of the protection zones in wetlands are kept smaller, and there are only policies that are aimed to prevent the direct losses. On the other hand, according to a study conducted by Houlahan et al. (2006), the misused areas around a wetland affect the habitat and its distribution in the nearby 
area in 250-300 m diameter. The studies conducted so far have demonstrated that the anthropogenic activities around the wetland affect the drainage, water quality and amount in a direct way. This leads to the loss of species and change in the flora of the area (Cobelas et al., 2001).

The highway causes the destruction of the habitat on its route and together with it, due to the excessive traffic on it, causes noise and air pollution, and similar other environmental problems, thus producing a pressure on the natural life in the area. The necessary precautions on the route must be taken, at least to decrease the effects of the vehicle transportation. The maximum speed limits of the vehicles must be decreased, and highrise blockages nearby the roads must be constructed and these areas must be planted, thus contributing to the efforts to decrease the negative effects of the road.

In addition to the environmental problems caused by the highway, the opening of the area for construction and the fast increase in buildings attract attention to the misuse of the area. Özbek and Öztaş (2004) conducted a study in Erzurum Plain and determined that 17637 da I. Class, 5422 da II. Class and 4061 da III. Class, in total 27150 da land were misused for nonagricultural purposes; and that in case water was used in the agricultural areas, there would be a net agricultural loss of around 2.5 million $\$$ a year. According to the investigations in the study, it has been determined that the I., II., III. Class agricultural areas were opened for construction with the building of the highway. In case a legal limitation is not set for the misuse of the area, the areas which have social, economic, and ecologic importance will be lost in time. In order to prevent this, the construction plans must be prepared by taking the ecological considerations into account when the economic benefits are cared for, and the local administrations must be decisive and consistent in applying these plans. The agricultural areas with high production potential must be defined as Absolute
Agricultural Areas in order to protect the ecological and agricultural balance and integrity and these areas must not be opened for construction.

The study results show that with the highway being built on the study area, which was once thought as being a less problematic area, the city of Erzurum has developed fast in this direction. This situation has caused the disappearance of important agricultural lands, the damage, even the destruction of the wetlands. As a result of this, the structure of the soil has changed, the plant and animal species are lost, the water regime of the area has changed, drought, and change in the climate occurred, which are irreversible changes, and these negative effects will be observed more in the study area.

The orbital road should have been made in an area with lower environmental sensitivity by analyzing the natural and cultural resources. Right at this point, construction must not be allowed around the road and the city must not be allowed to develop in that direction. For these reasons, the first thing in the area is stopping new construction permission. In addition, the buildings that will cause air, water and noise pollution in the wetland must also be stopped. In order to decrease the negative effects of the road, which is mostly used by heavy vehicles, and for the birds in the wetland, a buffer zone must be established in the roadside in $3 \mathrm{~m}$ elevation and with 10 meters width. The noise, dust and gas pollution in this zone may be decreased with evergreen plants such as the Scotch Pine (Pinus sylvestris L.), Oriental Arborvitae (Thuja orientalis L.), and Blue Chinese Arborvitae (Juniperus chinensis 'Pfitzeriana'). In addition, with a $3 \mathrm{~m}$ lifeless screen that will be placed in the middle of this buffer area, the efficiency of this barrier may be increased. Moreover, the birds may be prevented from seeing the vehicles during their stays in the wetland thus providing them with a safer environment (Fig. 4). 

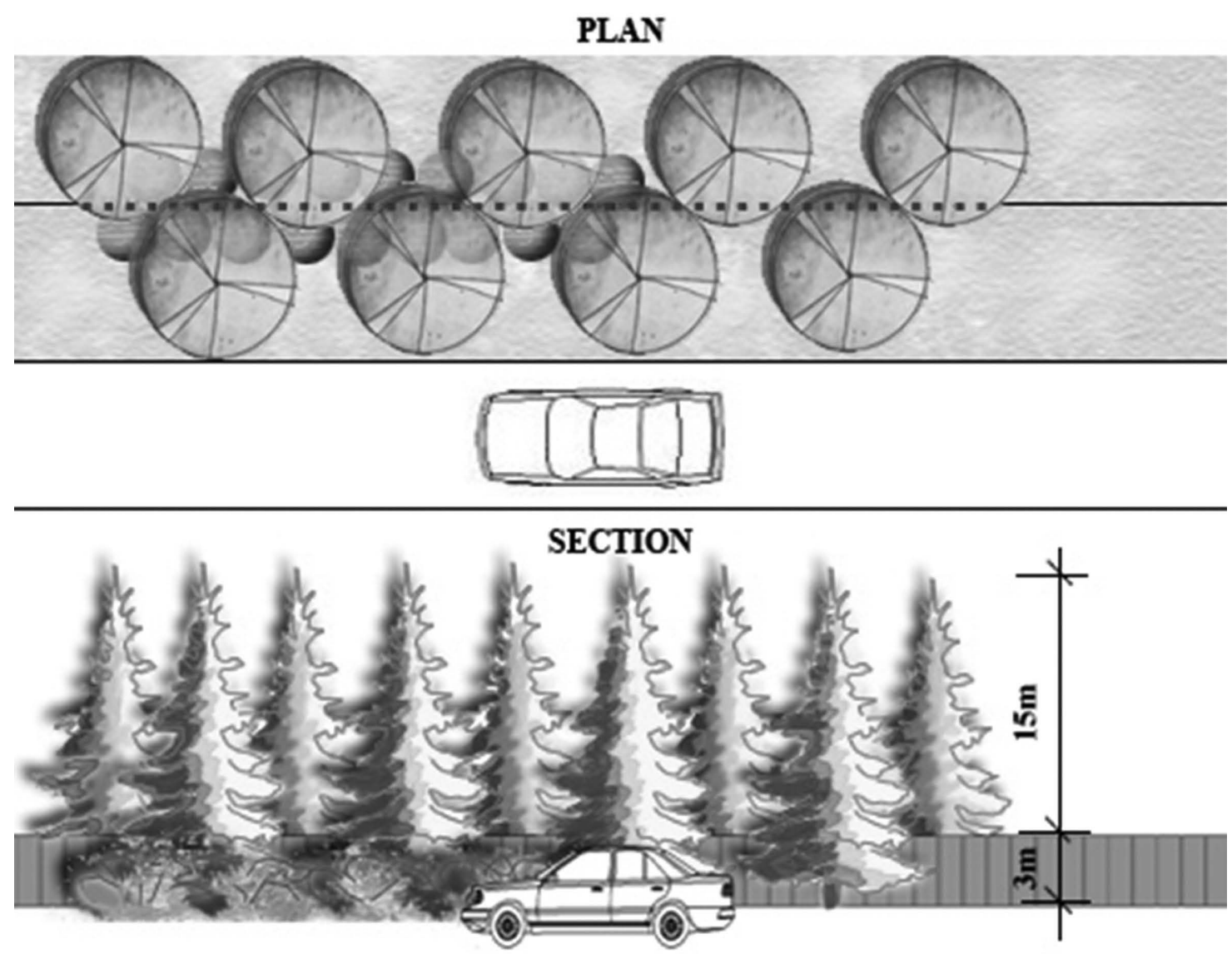

Figure 4. The Buffer Area Plan Proposal and Section to Decrease the Negative Effects of the Road

Human beings have always been inclined to choose the economy when left between selecting the nature and economy when they have thought in a short-term and shallow manner. However, in the long run, many negative effects appear related with these decisions. Actually, the decisions appear to be wrong in economic sense as well. In this sense, the decision makers in our country have to consider that choosing the easy and economical solution is not always the most accurate way in such situations.

\section{REFERENCES}

Anonim, 2000. Erzurum İli Arazi Varlığı. Köy Hizmetleri Genel Müdürlüğü Yayınları, Toprak Rapor No: 25, Erzurum.

Cobelasa MA, Cirujano S, Carrillo SS, 2001. Hydrological and botanical man-made changes in the Spanish wetland of Las Tablas de Daimiel. Biological Conservation, 97: 89-98.

Çakar HÖ, 2007. Antropojenik Baskıların Neden Olduğu Alan Kullanımı Değişimlerinin CBS ve Uzaktan Algılama Tekniği ile İncelenmesi: Balçova - Güzelbahçe Hattı Kıyı Kesimi Örneği. Ege Üniversitesi Fen Bilimleri Enstitüsü, Doktora Tezi, 176s.
Çelik K, 2007. Tarım Topraklarının Kentsel Arsa Olarak İmara Açılmasının Getirmiş Olduğu Sorunlar. TMMOB Harita ve Kadastro Mühendisleri Odas1 11. Türkiye Harita Bilimsel ve Teknik Kurultay1, 2-6 Nisan 2007, Ankara.

Demir M, Yıldız ND, Irmak MA, Yılmaz H, Yılmaz S, Özer S, 2011. Sulak Alanların Sürdürülebilirliği İçin Ekosisteme Bütüncül Yaklaşım: Erzurum Örneği. II. Türkiye Sulak Alanlar Kongresi, 22-24 Haziran 2011, Kırşehir.

Doygun N, Erdem Ü, 2013. Kentsel Gelişim Sürecinin Alan Kullanım Yapısı Üzerine Etkilerinin İncelenmesi: Bornova, İzmir Örneği. Türk Bilimsel Derlemeler Dergisi, 6 (1): 17-22.

Eken G, Bozdoğan M, İsfendiyaroğlu S, Kılıç DT, Lise Y, 2006. Türkiye'nin Önemli Doğa Alanları. Doğa Derneği, Ankara, $632 \mathrm{~s}$.

Ekşioğlu S, Erdem O, Sevindi C, İsfendiyaroğlu S, 2006. Erzurum Bataklıkları. Türkiye'nin Önemli Doğa Alanları, Doğa Derneği, Cilt 2, 288-289, Ankara.

Findlay CS and Bourdages J, 2000. Response time of wetland biodiversity to road construction on adjacent lands. Conservation Biology 14(1): 86-94.

Houghton RA, 1994. The Worldwide Extent of Land-Use Change, BioScience, 44(5): 305-313.

Houlahan JE, Keddy PA, Makkay K and Findlay CS, 2006. The effects of adjacent land use on wetland species richness and community composition. Wetlands, 26(1): 79-96. 
Irmak MA, 2008. Erzurum Ili ve Yakın Cevresinin Flora Turizmi Potansiyeli Açısından Değerlendirilmesi. Atatürk Üniversitesi Fen Bilimleri Enstitüsü, Doktora Tezi, 248s.

Lambin EF, Rounsevell MDA and Geist HJ, 2000. Are agricultural land-use models able to predict changes in land-use intensity? Agriculture, Ecosystems and Environment, 82: 321-331.

Ningal T, Hartemink AE, Bregt AK, 2008. Land use change and population growth in the Morobe Province of Papua New Guinea between 1975 and 2000. Journal of Environmental Management, 87: 117-124.
Özbek AK, Öztaș T, 2004. Tarım Arazilerinin Amaç Dıșı Kullanımı; Erzurum Örneği. Ekoloji, 13(52): 1-6.

Rimal B, 2011. Urban Growth and Land use/Land Cover Change of Biratnagar Sub-Metropolitan city, Nepal. Applied Remote Sensing Journal, 2(1): 6-15.

Tunay M, Yılmaz B, Ateşoğlu A, 2008. Bartın-Amasra Karayolu Güzergahının Doğal Peyzaj Özellikleri Üzerindeki Etkilerinin Saptanmas1. Ekoloji, 66: 23-30. 
